\title{
A cidade do Rio de Janeiro e a construção do Aeroporto Santos Dumont (1933-1938)
}

The city of Rio de Janeiro and the construction of the Santos Dumont Airport (19931938)

\author{
Claudia Musa Fay*
}

\begin{abstract}
Resumo
A cidade do Rio de Janeiro da década de 1930 foi marcada por intervenções urbanas, como a construção do Aeroporto Santos Dumont, objeto de estudo deste artigo, que focaliza seu projeto e sua localização. Situado na ponta do Calabouço, a poucos minutos do centro da cidade, mereceu um debate na imprensa que despertou o interesse de vários setores. $\mathrm{O}$ objetivo foi analisar as repercussões da obra para a cidade, confrontando a posição dos técnicos do Departamento de Aviação Civil com o plano idealizado pelo urbanista francês Alfred Agache.
\end{abstract}

Palavras-chave: Urbanização; Rio de Janeiro; Aeroporto.

\begin{abstract}
The city of Rio de Janeiro of the 30's decade was marked by urban interventions, highlighting in this article the construction of the Santos Dumont Airport, focusing on the project and location. Situated at the edge of the dungeon, a few minutes from the center of the city, deserved a debate in the press that revealed the interest of many sectors. The objective was to analyse the repercussions of the work to the city, confronting the position of technicals of the Civil Aviation Department with the plan idealized by the french urbanist Alfred Agache.
\end{abstract}

Keywords: Urbanization; Rio de Janeiro; Airport.

"O avião é, sem dúvida, uma máquina, mais que instrumento de análise! Este instrumento permitiu-nos descobrir a verdadeira face da Terra." (SAINTEXUPÉRY, 1986, p. 39).

\section{Introdução}

A paisagem urbana do Rio de Janeiro se modificou nas primeiras décadas do século XX e entre tantas mudanças nesse período, destaca-se, no contexto socioeconômico e cultural da cidade, a construção do Aeroporto Santos Dumont.

\footnotetext{
* Doutora em História pela Universidade Federal do Rio Grande do Sul (UFRGS). Professora do Programa de Pós-graduação em História da Pontifícia Universidade Católica do Rio Grande do Sul (PUCRS).
} 
Segundo Pesavento (1995), a cidade é o espaço por excelência para a construção de significados, expressos em bens culturais. Busca-se, neste estudo, compreender o fenômeno urbano por meio do cruzamento de imagens, práticas sociais e discursos, utilizando os conceitos de representação e de imaginário, os quais, segundo Chartier (2002), auxiliam a pensar o mundo social ou o exercício do poder de acordo com um modelo relacional. Para esse autor, as práticas são produzidas por representação, por meio das quais os indivíduos dão sentido ao mundo que veem (CHARTIER, 2002). Por meio da abordagem interdisciplinar proposta pela História Cultural, utiliza-se a metodologia preconizada por Ginzburg (1989), partindo de indícios encontrados em fotos, plantas urbanas e discursos, para reconstituir o que pensavam ou tentavam expressar os homens do passado.

A invenção do avião foi um fato novo na história da tecnologia. Como refere Emmanuel Chadeau (1996, p. 42), ele não substitui nenhuma máquina ou nenhuma utilidade social existente; o avião é totalmente novo e, para fazê-lo circular, foi necessário criar uma infraestrutura e regras. Por essa razão, as cidades precisaram se adaptar e criar locais para recebê-lo.

Como ocorreu com as estações ferroviárias no século XIX, os anos 1930 do século XX foram marcados pela construção de aeroportos, porque o embarque e desembarque de passageiros necessitava de um ponto de encontro, que fosse funcional e estético, assim como o novo meio de transporte. Essa tendência que dominou na Europa partiu da Alemanha de Weimar, especialmente da Bauhaus e do futurismo italiano, surgindo da disposição de unificar, se não a realização dos arquitetos, ao menos o espírito de seus projetos.

O crescimento do transporte aéreo demandava a necessidade de campos de pouso cada vez maiores, bem como a construção de pistas, com seus terminais para passageiros, hangares e demais dependências, o que suscitou uma nova forma de arquitetura (WOHL, 2005, p. 314). Roseau (2014) explica a ligação entre os primeiros aeroportos e a história urbana, relacionando-os aos eventos para o grande público, a saber: a Exposição em Paris de 1937 e o aeroporto de Le Bourget; o $700^{\circ}$ aniversário de Berlim e a reconstrução do aeroporto de Tempelhof; e a World Fair de Nova York e o Aeroporto de La Guardia em 1939. No momento que se projeta um grande evento metropolitano, pensa-se no ingresso de muitas pessoas e o aeroporto é a porta que se abre para o mundo. Ainda segundo Roseau (2012), a invenção do aeroporto moderno modificou as cidades, provocou uma mutação na percepção do espaço e renovou as 
formas de representação. Foi o debate transnacional sobre a cidade como espaço suscetível de ser reformado pela nova modalidade de transporte, que proporcionou o encolhimento das distâncias e, ao mesmo tempo, um debate sobre o futuro das cidades. O aeroporto, como símbolo de poder, inovação e tecnologia, passou a ser a "porta de entrada" e também uma vitrine, farol emblemático de entrada das metrópoles no cenário internacional, que possibilitava mostrar para a população os avanços tecnológicos e colocavam a cidade no mapa (ROSEAU, 2012).

O Rio de Janeiro, na década de 1930, insere-se nesse momento histórico, quando políticos e técnicos pretendiam dotar a cidade de uma vitrine para o mundo, mas a escolha do local adequado provocou uma discussão entre técnicos ligados a aeronáutica, arquitetos e urbanistas.

A capital federal de um país, como o Brasil, tornou-se um ponto de passagem e de chegada para os aviões franceses, alemães, italianos e norte-americanos que voavam para América do Sul. Em 25 de maio de 1930 causou encantamento na população carioca a passagem do Zeppelin, sobrevoando toda a cidade e mereceu um amplo registro fotográfico, que foi publicado nas semanas seguintes pela revista $\mathbf{O}$ Cruzeiro e por alguns jornais, mostrando a possibilidade da viagem entre a Europa e América do Sul em três dias (HEMEROTECA DIGITAL DA BIBLIOTECA NACIONAL, 31/05/1930, p. 1). ${ }^{1}$

Segundo Sevcenko (1998, p. 522), a cidade do Rio de Janeiro representava o papel de metrópole-modelo, sede do governo, centro cultural, maior porto e maior cidade. Mauad (2005, p. 166), ao estudar as fotografias publicadas nas revistas ilustradas, ressalta a coesão de classe e a construção de uma capital cosmopolita e moderna, plenamente preenchida por valores burgueses, pela vivência e pelo consumo de um mesmo universo de signos, visando moldar a cidade à semelhança dos padrões europeu e norte-americano.

O desmonte do morro do Castelo, iniciado em 1920, para a exposição do centenário da independência em 1922, a abertura de avenidas e o plano diretor encomendado ao arquiteto e urbanista francês Alfred Agache demonstraram a preocupação das autoridades em remodelar a cidade. Essa ideia continuou com a chegada de Vargas ao governo em 1930 com a intenção de modernizar a capital.

\footnotetext{
${ }^{1}$ Hemeroteca digital da Biblioteca nacional. Periódicos. O Cruzeiro, Rio de Janeiro, 31 maio 1930. p. 1.
} 
Buscou-se, neste artigo, por meio da imprensa, confrontar as ideias e as políticas públicas em relação à construção do aeroporto, especialmente as reportagens publicadas na revista $\mathbf{O}$ Cruzeiro e no jornal Correio da Manhã. ${ }^{2}$

A revista $\mathbf{O}$ Cruzeiro representava uma proposta ambiciosa do jornalista Assis Chateaubriand, lançada em dezembro de 1928. "A revista dos arranha céus", que desejava "atravessar o Brasil de extremo a extremo", era impressa em quatro cores, trazia diversas fotografias, utilizava papel da melhor qualidade, contava com grandes jornalistas e teve uma tiragem inicial de 50 mil exemplares (DICIONÁRIO HISTÓRICO BIOGRÁFICO BRASILEIRO, 2001, p. 1727). O Correio da Manhã, por sua vez, era um jornal carioca tradicional, fundado em 1901 por Edmundo Bittencourt, e um dos principais órgãos da imprensa brasileira (DICIONÁRIO HISTÓRICO BIOGRÁFICO BRASILEIRO, 2001, p. 1625).

O Correio da Manhã adotou uma posição ambígua, apoiando parcialmente Getúlio Vargas. Como explica Eleutério (2008, p. 84), o jornal, a revista e o cartaz aliavam-se às melhorias dos transportes, ampliando os meios de comunicação e potencializando o consumo de toda ordem. Segundo a autora, a evolução da técnica do impresso, o investimento na alfabetização e os incentivos à aquisição de papel foram muito importantes, pois baratearam o preço dos impressos. Também são relevantes o telefone, o telégrafo, o envio de correspondentes para o exterior e a contratação de agências internacionais, haja vista que, devido às dimensões continentais do Brasil, as mudanças técnicas significaram um elo internacional.

O avião nessa época, embora de pequenas dimensões, podia transportar entre duas e três toneladas e realizar etapas de 800 a $1.500 \mathrm{~km}$, transmudando de oito a quinze passageiros e suas bagagens; os preços, no entanto, eram exorbitantes, uma vez que, com a oferta de poucos lugares, o avião por quilômetro percorrido custava duas a três vezes mais que os trens de luxo (CHADEAU, 1996, p. 139).

Contudo, a velocidade e a capacidade de transpor obstáculos fazia grande diferença, aproximando-se dos 300 a $400 \mathrm{~km}$ por hora. Como se pode inferir nos Planos da VASP para a realização da linha Rio-São Paulo 1933, o estudo da empresa para viabilidade do transporte comparava o avião com os navios que levavam doze dias da Europa ao Brasil, enquanto o avião fazia em três dias esse mesmo percurso. Uma viagem de trem entre o Rio de Janeiro e São Paulo levava em torno de doze horas, e um

\footnotetext{
${ }^{2}$ Os jornais supracitados encontram-se disponíveis para consulta na Hemeroteca Digital da Biblioteca Nacional. Disponível em: 〈http://memoria.bn.br/hdb/uf.aspx >.
} 
trem razoável, percorrendo essa distância a 100 km, levaria seis horas, mas no Brasil não havia esse trem. Segundo a proposta da empresa, o avião levava enorme vantagem, pois ligava as duas maiores cidades do país em uma hora e dez minutos com conforto, regularidade e segurança (VASP, Aviação Comercial, s/d).

Na época, a comunicação entre São Paulo e Rio era difícil pela falta de aeroportos adequados. Enquanto o uso dos hidroaviões permitia que do Rio Grande do Sul à capital se fizesse uma viagem em cinco horas, assim como ao levantar voo da Bahia era possível chegar ao Rio de Janeiro em seis horas, de São Paulo o tempo mínimo para atingir a urbe carioca eram doze horas. Como São Paulo estava longe do mar e os aparelhos utilizados no início pela aviação comercial brasileira voavam no litoral, a cidade não possuía esse serviço. Os voos postais da Latécoère, do Syndicato Condor e da Panair do Brasil que tinham escalas paravam em Santos, e não na cidade de São Paulo.

A questão das comunicações era tão grave que uma ligação telefônica entre as duas capitais, muitas vezes, exigia a espera de duas a três horas e a ligação aérea podia ser feita em setenta minutos. Em entrevista, o diretor gerente da Vasp forneceu o exemplo dos jornais diários que eram distribuídos às 20h, enquanto em Porto Alegre e Salvador os jornais já eram lidos às $13 \mathrm{~h}$.

O governo Vargas foi sensível à nova tecnologia e passou a apoiar o desenvolvimento da aviação comercial criando, em 22 de abril de 1931, o Departamento de Aeronáutica Civil, órgão administrativo encarregado de criar leis e regular a navegação aérea. Outra demonstração de interesse por parte do governo foi o apoio à instalação de uma fábrica de aviões no Brasil, mas a maior iniciativa foi, sem dúvida, a construção do aeroporto do Rio de Janeiro.

A questão da construção de infraestrutura para o novo meio de transporte era global. A maior parte dos estudos considerava ideal construir o aeroporto no coração das cidades, como ocorreu em Berlim, com o Tempelhof, em que o terreno escolhido era um campo de manobras do exército alemão no tempo do Keiser. A necessidade de criar um local destinado à aviação como meio de transporte fez com que o governo alemão instalasse seu aeroporto nesse local a três quilômetros - aproximadamente quinze minutos - do centro. Foi inaugurado em 1923 durante a República de Weimar e remodelado pelo Regime Nazista.

Os aeroportos de Paris e de Bruxelas seguiram outra concepção e foram estabelecidos longe do centro por falta de terrenos adequados. Dessa forma, o tempo da 
viagem aérea era acrescido do trajeto de automóvel dos aeroportos ao centro daquelas cidades. O tempo da viagem muitas vezes tornava-se maior que o despendido pela estrada de ferro entre as mesmas cidades, cujas estações ferroviárias estavam situadas no centro urbano. Isso ocorria no percurso de Paris a Londres pelo ar, não obstante a economia de tempo, de baldeações em Calais e Dover, obrigatórias no transporte misto ferroviário e marítimo, pois grande parte do tempo era perdido no transporte de Paris ao aeroporto Le Bourget e do aeroporto Croydon em Londres.

A possibilidade de realizar viagens com o apoio do governo brasileiro oportunizou aos técnicos do Departamento de Aeronáutica Civil conhecer as diversas soluções adotadas nesses países e realizar um projeto para a cidade do Rio de Janeiro, na época Capital Federal.

\section{O Plano Agache e a proposta para a ponta do Calabouço}

A preocupação com a urbanização da cidade motivou o convite para a visita e realização de uma série de conferências do arquiteto urbanista francês Alfred Agache ${ }^{3}$ pelo prefeito Antônio Prado Junior, em 1927. No ano seguinte, ele foi contratado para realizar uma proposta de intervenção urbanística na cidade do Rio de Janeiro, com preocupações modernas. Agache, na ocasião, explicou que a elaboração de um bom plano de cidade exigia, antes de tudo, tomar conhecimento da história e da geografia do lugar, do seu passado, e interpretar as estatísticas para previsão de futuro.

O recurso trazido pela aviação para a aerofotografia foi utilizado pelo urbanista para realizar a planta da cidade. A revista O Cruzeiro estava no segundo mês de circulação quando publicou uma matéria assinada pelo Capitão Tenente Netto dos Reis, aviador naval, descrevendo os progressos da aviação e da fotografia aérea. Entre as belezas descritas pela oportunidade de ter a visão aérea do Rio de Janeiro com suas praias de recortes bem definidos, suas casas de tetos multicores, suas ruas e avenidas, o aviador explicou como era feita a fotografia aérea, realizando um levantamento da região a quatro mil metros de altura.

\footnotetext{
${ }^{3}$ Alfred Hubert Donat Agache (1895-1959) foi convidado para visitar o Brasil em 25 de junho de 1927. Seu Plano foi publicado na França em 1930 e no Brasil em 1932.
} 
Atrás, acompanhando interessado o trabalho de sua máquina fotográfica, meu companheiro, o observador, conseguia imprimir vistas sucessivas sobre faixas paralelas do terreno que percorríamos ora num, ora no outro sentido, segundo suas indicações. (HEMEROTECA DIGITAL DA BIBLIOTECA NACIONAL, 29/12/1928, p. 13). ${ }^{4}$

No seu Plano, Alfred Agache desejava embelezar a cidade, mas tinha outras preocupações como a circulação, o transporte das massas, o abastecimento de água, o saneamento, a habitação operária e o crescimento das favelas. Estudou o caso da Navegação Aérea e considerou que o Rio de Janeiro possuía três locais adequados para instalar aeroportos: o Campo dos Afonsos, distante do centro cerca de 25 quilômetros, que deveria ser destinado para instrução e formação de pilotos; e para a aviação comercial foram destinados dois locais - a estação para aviação marítima na Península do Calabouço; e para a aviação internacional outro local na ilha do Fundão e ilhas circunvizinhas, próximas à Ilha do Governador onde havia um campo de hidroaviação militar (AGACHE, 1930, p. 186).

Agache, por meio de fotos aéreas, demonstrou a necessidade de se ampliar o núcleo central do Rio de Janeiro. Na sua visão, com o comércio, a sede de bancos e as repartições administrativas encontravam-se fechados e abafados por dois morros, o do Castelo e o de Santo Antônio, que comprimiam a Avenida Rio Branco e concentravam a circulação nesta artéria da cidade. Como pode ser visto no esquema abaixo desenhado por ele, o Castelo havia começado a ser posto abaixo no período de Carlos Sampaio (1920-1922) e terminado em 1928; restava o Santo Antonio.

\footnotetext{
${ }^{4}$ Hemeroteca digital da Biblioteca nacional. Periódicos. O Cruzeiro, Rio de Janeiro, 29 dez. 1928. p. 13.
} 


\section{Figura 1 - Morro do Castelo e Santo Antonio}

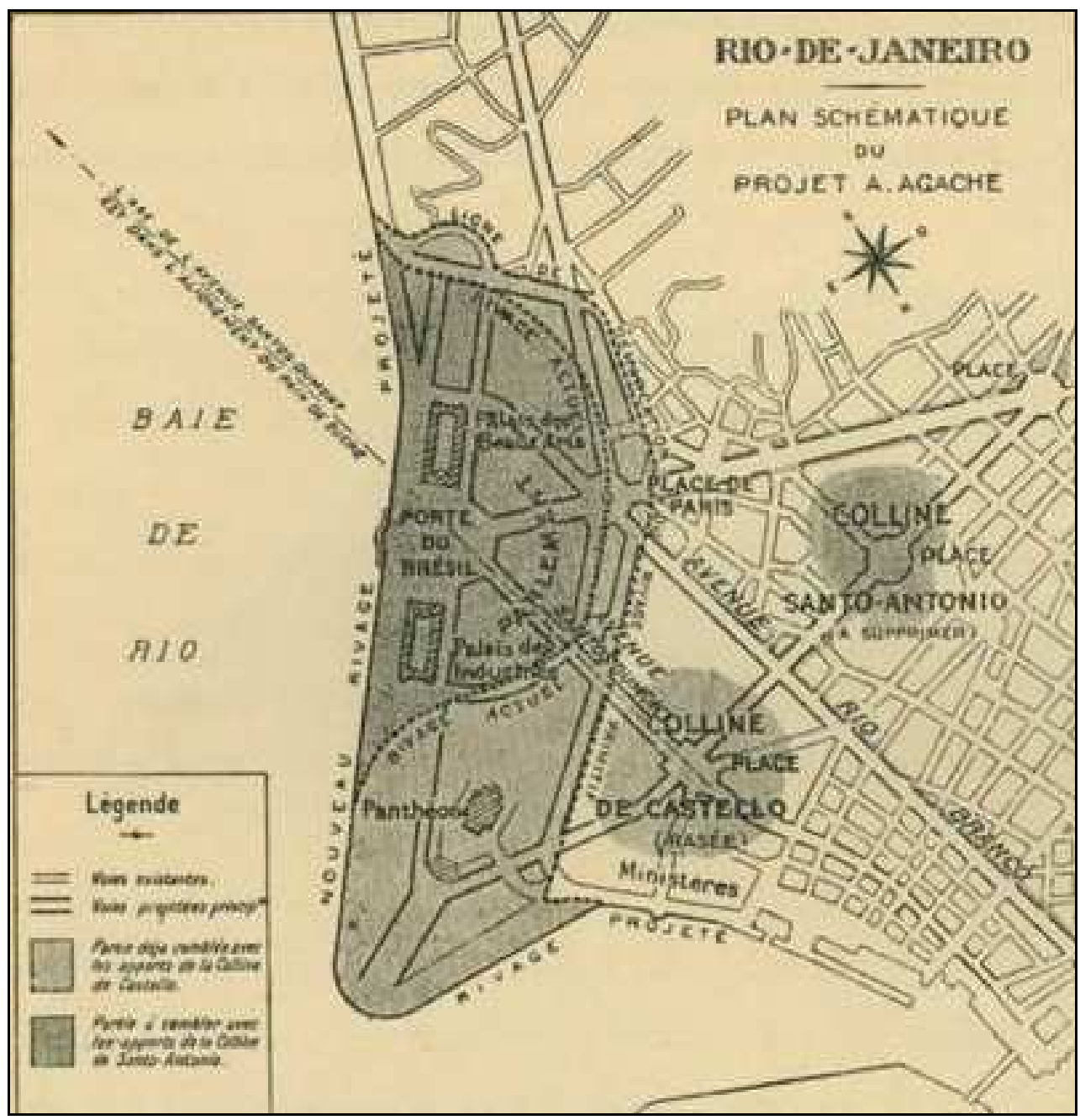

Fonte: Agache (1930).

Na figura 1, estão identificados os dois morros, que ele chama de Colline de Castelo e Colline Santo Antonio. Ambos cercavam a Avenida Rio Branco e, com o desmonte, a terra retirada dos dois morros serviu para aterrar uma parte da baía. $\mathrm{Na}$ figura 2, aparece a Ponta do Calabouço, área que anteriormente era mar e onde o arquiteto planejou um jardim. 
Figura 2 - Ponta do Calabouço

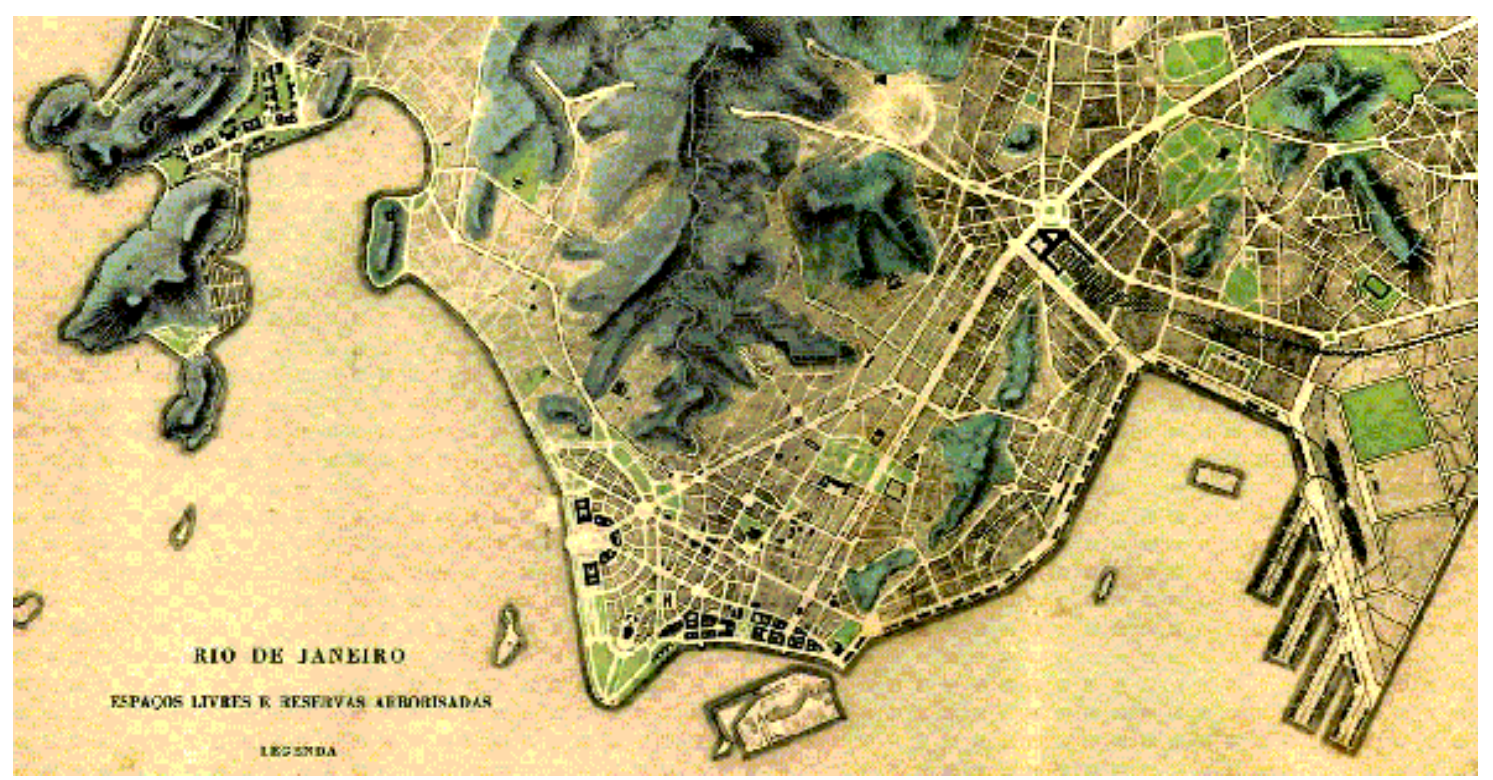

Fonte: (AGACHE, 1930).

Figura 3 - Ponta do Calabouço

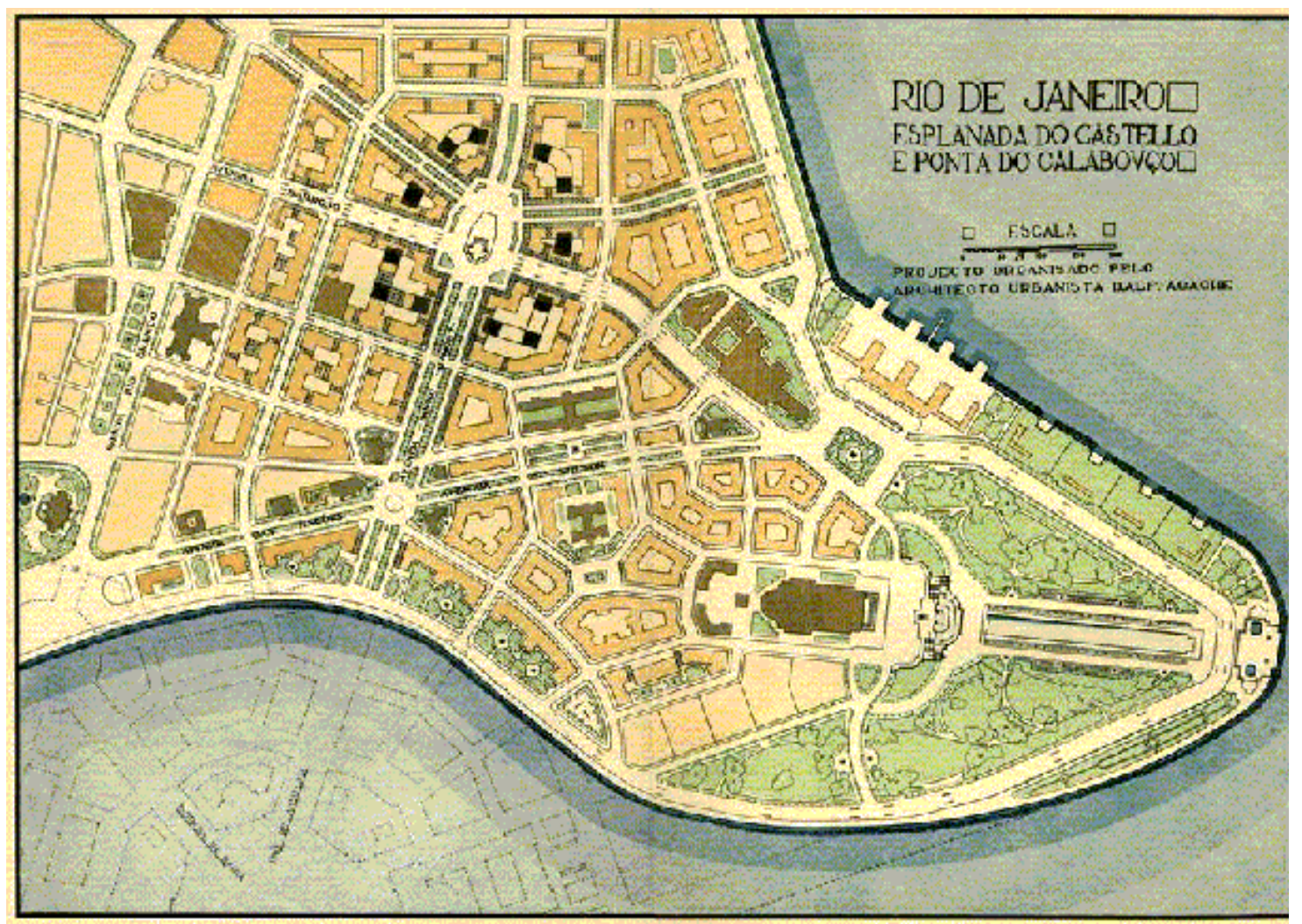

Fonte: (AGACHE, 1930). 
A figura 3 traz uma vista aérea dos jardins planejados por Agache. Para a nova área resultante do aterro, ele desenhou um grande e frondoso jardim, inteiramente voltado para o mar, com ampla visão para o fundo da baía de Guanabara até a Serra dos Órgãos. Pode ser observado, sobre outro ângulo, na figura 4, um jardim tropical com palmeiras e um grande espelho d'água.

\section{Figura 4 - Jardins projetados na Ponta do Calabouço}

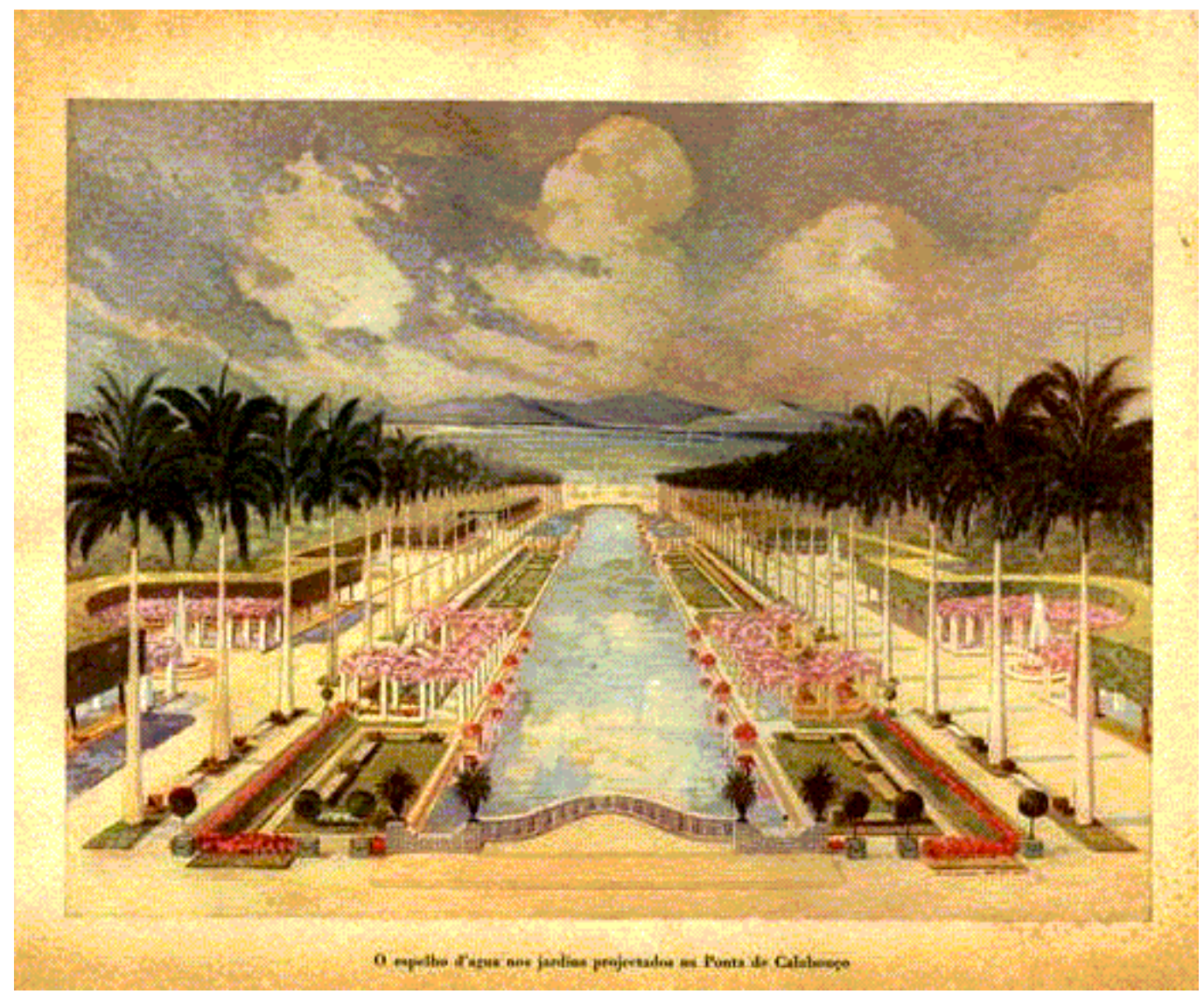

Fonte: (AGACHE, 1930).

\section{O Projeto proposto pelos técnicos do Departamento de Aviação Civil para o}

\section{Aeroporto Santos Dumont}

Os técnicos do Departamento de Aviação Civil não aceitavam que área tão nobre fosse ocupada por um jardim. Planejavam criar um aeroporto na área aterrada, causando uma polêmica com os defensores do projeto de Alfred Agache. O Engenheiro César da Silveira Grillo, que desde 1926 era responsável pelo Serviço de Navegação Aérea do Ministério de Viação e Obras Públicas, dedicou-se a difundir, por meio da imprensa e 
de reuniões no Clube de Engenharia, as vantagens que a cidade teria com a construção de um aeroporto central na ponta do Calabouço.

César Grillo e seus técnicos pretendiam ampliar a área aterrada e colocar o aeroporto de frente para a baía e próximo ao coração da cidade. No Plano do urbanista francês, o aeroporto estava previsto nos terrenos de Manguinhos, onde funcionava o Aeroclube do Brasil ${ }^{5}$. Essa ideia era rebatida pelos técnicos do Departamento de Aviação Civil que consideravam o local impróprio, especialmente pela distância de doze quilômetros do centro, numa cidade com grandes dificuldades de circulação.

Verificando os jornais da época, percebe-se que as resistências eram difusas em relação à área aterrada; além do projeto do magnífico jardim, alguns desejavam que a área fosse ocupada pela construção imobiliária de arranha-céus, ao passo que outros consideravam o espaço pequeno para a construção de pistas e até mesmo alegavam que o ruído provocado pelos motores e a proximidade ao centro causariam incômodos (BARBOSA, 1985, p. 19).

Personalidades ligadas à aeronáutica que passavam pelo Rio de Janeiro eram convidadas a emitir opinião sobre a localização do aeroporto e seus pareceres eram arquivados no Departamento de Aviação Civil e divulgados nos jornais. Foram muitos os depoimentos, como o do aviador francês Jean Mermoz, o primeiro a fazer a travessia aérea do Atlântico Sul, que assim se manifestou a respeito: "A presença de um aeródromo tão perto da cidade só pode ter influência feliz sobre o desenvolvimento do espírito aeronáutico no Brasil." (BARBOSA, 1985, p. 23).

Outra voz que concordava com a localização do aeroporto próximo do centro foi a de Hugo Eckener, chefe da empresa Luftschiff, à qual pertencia o "Graf Zeppelin". Em 1932, o governo alemão ofereceu uma viagem para três jornalistas brasileiros com o intuito de demonstrar que a empresa desejava instalar uma base completa para pouso no Rio de Janeiro, visando à aceleração do tráfego de passageiros e da correspondência entre a Europa e América do Sul. A ideia era construir no Rio de Janeiro uma estação final da linha aérea e, dessa forma, a cidade não seria visitada pelo dirigível raramente, mas seria um ponto significativo (HEMEROTECA DIGITAL DA BIBLIOTECA NACIONAL, 13/10/1932, p. 6). ${ }^{6}$

\footnotetext{
${ }^{5}$ O Aeroclube funcionou nesse local até 1960, quando foi transferido.

${ }^{6}$ HeMERoteca digital da BIBlioteca nACIONAL. Periódicos. O Cruzeiro, Rio de Janeiro, 13 out. 1932. p. 6 .
} 


\section{Aviação e Turismo}

O Engenheiro César Grillo continuava a defender com entusiasmo o projeto do mais belo aeroporto do mundo, ressaltando a importância de uma linha aérea de Zepelins entre a Alemanha e o Brasil, a qual seria a primeira linha aérea do mundo regular, unindo um continente ao outro. Fazendo uma ligação direta de um centro ao outro, propunha um local especial para os gigantes do ar.

O Dr. César Grillo acreditava que a iniciativa possuía um aspecto importante: desenvolver o turismo na cidade. Feita a ligação direta da Europa, o Rio de Janeiro seria o elo com outras cidades da América do Sul. O Ministério de Viação, acreditando na proposta dos alemães e, com o amparo do governo, ofereceu um terreno no Recreio de Bandeirantes, na Gávea. O terreno se prestava à construção do hangar por ser a direção dos ventos mais constante. O Zeppelin, ao contrário do avião, era uma grande massa e sofria com as mudanças bruscas do meio ambiente. Na mesma entrevista concedida ao jornal, o engenheiro César Grillo explicou que o ideal seria construir um aeroporto central, na ponta do Calabouço. Situado ao lado do porto e do coração da cidade, ali seria construída uma estação de passageiros para embarque e desembarque não só de aviões e hidroaviões, mas também de Zeppelins. A direção do vento no local é sempre constante norte ou sul, condição básica de eficiência de um aeroporto. Para o Zeppelin seria construída uma torre movediça, onde o amarrariam, mal chegasse da Europa para deixar os passageiros ou quando tivesse que regressar. A torre ficaria normalmente abaixada, dentro de uma vala, coberta com lápides transparentes e com um belo efeito de iluminação. Como a viagem de longo curso era extremamente cara, a empresa pretendia oferecer o Zeppelin-Ônibus para os que não podiam pagar a passagem de um voo para a Europa. Seria um voo sobre a cidade que já daria a sensação desse novo meio de transporte, pagando uma passagem popular; seria mais um meio de admirar as belezas do Rio de Janeiro (HEMEROTECA DIGITAL DA BIBLIOTECA NACIONAL, 14/10/1932, p. 5). ${ }^{7}$

A intenção do Dr. Eckener e da empresa que ele representava era enviar, rapidamente, em dois meses, os planos de construção da infraestrutura, contando com o apoio do governo alemão. Na realização da obra seria empregado material e pessoal nacional e a previsão seria realizar a construção em oito meses.

\footnotetext{
${ }^{7}$ Hemeroteca digital da Biblioteca nacional. Periódicos. O Cruzeiro, Rio de Janeiro, 14 out. 1932. p. 5 .
} 
A vinda dos aviões e dos aviadores era publicada em fotografias nas revistas ilustradas, possibilitando uma maior divulgação das imagens aéreas e da paisagem vista do alto para o grande público. Eram imagens de um Rio de Janeiro pouco visto, mas muito atraente para os olhos, porque suas qualidades turísticas foram ressaltadas. Sempre reforçando a ideia da necessidade do novo aeroporto para receber os turistas, pensava-se que quando a cidade possuísse o seu aeroporto central, a chegada do turista seria profundamente deslumbrante, de frente para a baía, o cartão postal da cidade. A revista prometia que a metrópole ficaria animada e se faria sentir na vida social e nos hábitos do carioca (HEMEROTECA DIGITAL DA BIBLIOTECA NACIONAL, 13/10/1934, p. 67). ${ }^{8}$

O norte-americano M. J. Rice, vice-presidente da companhia aérea Panair do Brasil, mostrava-se muito entusiasmado com a construção do aeroporto, tanto que disse aos jornalistas, ao chegar ao Rio, que poucos países ofereciam aspectos naturais tão propícios ao desenvolvimento do turismo. Mostrou números para comprovar que crescia significativamente o número de passageiros que utilizavam o Pan American Airways System da Panair do Brasil para fins de turismo. Com o início das operações do aeroporto na ponta do Calabouço, esse turista chegaria à capital do Brasil através do portal magnífico de um dos mais belos aeroportos do mundo (HEMEROTECA DIGITAL DA BIBLIOTECA NACIONAL, 20/10/1934, p. 6). ${ }^{9}$

O Comissário do Turismo do Rio de Janeiro, Lourival Fontes, também salientava o movimento de negócios produzidos pelo turismo na França, Itália e Alemanha. Segundo ele, nenhuma outra cidade podia reunir tantas riquezas naturais e tão variadas como o Rio de Janeiro. Destacava também os eventos que ocorriam na cidade - as corridas de automóvel, o grande prêmio no hipódromo Jockey Club, os concursos de competições atléticas e o carnaval carioca - como atrações oferecidas para o grande público (HEMEROTECA DIGITAL DA BIBLIOTECA NACIONAL, 20/10/1934, p. 8). ${ }^{10}$

Ao mesmo tempo era possível notar que havia jornalistas mais críticos que alertavam, ao falar de turismo aéreo no Rio de Janeiro, que a cidade estava situada num

\footnotetext{
${ }^{8}$ Hemeroteca digital da biblioteca nacional. Periódicos. O Cruzeiro, Rio de Janeiro, 13 out. 1934. p. 67.

${ }^{9}$ Hemeroteca digital Da Biblioteca nacional. Periódicos. O Cruzeiro, Rio de Janeiro, 20 out. 1934. p. 6.

${ }^{10}$ Hemeroteca Digital Da BIBlioteCA NACIONAL. Periódicos. O Cruzeiro, Rio de Janeiro, 20 out. 1934. p. 8.
} 
ponto de fácil acessibilidade, tanto do turismo europeu como do da América do Norte, e ressaltavam que não bastavam as belezas e o clima para atraí-los. Era preciso tornar as viagens conhecidas do público.

Havia por parte das empresas aéreas um especial cuidado em sempre oferecer viagens de cortesia para os formadores de opinião. Desejavam mostrar aos políticos e jornalistas a eficiência dos serviços oferecidos e a segurança das viagens. Tanto no Zeppelin como por ocasião do Brazilian Clipper na aeronave da Pan American Airways Sistem, pessoas importantes e jornalistas eram convidados e suas reportagens contribuíam para revelar à grande massa de leitores as experiências do voo.

Outra forma de obter publicidade foi pelo cinema. O filme "Voando para o Rio" (Flying to Rio), realizado em 1934, mostrou o Rio de Janeiro como cenário do cinema de Hollywood. Estrelado por atores famosos como Fred Astaire e Dolores del Rio, o filme proporcionou, para milhares de pessoas através do mundo, a divulgação das belas paisagens do Rio, suas ruas, avenidas e jardins, tudo visto do alto, com imagens captadas por cinegrafistas nos aviões da Panair. A revista dedicou um número especial para ressaltar essa iniciativa do cinema norte-americano (HEMEROTECA DIGITAL DA BIBLIOTECA NACIONAL, 20/10/1934, p. 8). ${ }^{11}$

Além do apoio dos meios de comunicação, a proposta de César Grillo para construção do aeroporto teve o apoio do governo e do próprio presidente Getúlio Vargas. Chadeau (1996, p. 193) explica que a construção de aeroportos foi considerada pelos governantes da época uma forma de poder e modernidade. As visões das máquinas provocavam o fascínio tanto para os que não tinham condições econômicas de pagar as passagens como para os viajantes, porque o aeroporto era o local na terra em que ocorria o embarque e o desembarque, a partida e a chegada, e também oferecia a visão da máquina, reunindo um público desejoso apenas de olhar.

Vargas que, na época, era considerado pela imprensa "amigo da aviação", percebeu o instrumento político que o avião significava e seu governo forneceu um amplo apoio na resolução dos problemas aeronáuticos.

Ao identificar na aviação uma forma nova e moderna de transporte, o governo soube adotar medidas para o desenvolvimento da aviação civil, sem se esquecer do fomento aos aeroclubes, a fabricação de aparelhos nacionais e o amparo por meio de cursos para aperfeiçoamento de pilotos civis e militares. O Presidente, em suas viagens,

\footnotetext{
${ }^{11}$ Hemeroteca digital DA BIBlioteCA nACIONAL. Periódicos. O Cruzeiro, Rio de Janeiro, 20 out. 1934. p. 23.
} 
dava nítida preferência ao transporte aéreo, sempre fotografado embarcando ou desembarcando de aviões. A revista $\mathbf{O}$ Cruzeiro fez uma reportagem relacionando as horas voadas pelo Presidente durante dez anos de governo:

\begin{abstract}
O presidente voa
O avião é seu veículo predileto. Entre dezembro de 1930 a dezembro de 1940 realizou viagens aéreas no total de 647 horas, 81.000 milhas percorridas. $\mathrm{Na}$ Condor de 2 de março de 1929 até 9 de janeiro de 1940, o presidente Getúlio Vargas percorreu $13.980 \mathrm{~km}$ somando 78 horas; as viagens foram na maioria do Rio de Janeiro para Porto Alegre e entre as cidades do sul. Na Panair de 29 de setembro 1933 até maio de 1941, o presidente percorreu $12.331 \mathrm{~km}$, num total de 60 horas e 20 minutos. As viagens foram feitas tanto para o norte como para o sul (HEMEROTECA DIGITAL DA BIBLIOTECA NACIONAL, 6/09/1941, p. 62). ${ }^{12}$
\end{abstract}

Apoiar a construção do aeroporto foi mais uma demonstração da necessidade que o novo meio de transporte se tornara. $\mathrm{O}$ apoio do governo, da imprensa e das personalidades aeronáuticas possibilitou a aprovação do Plano Geral para o Aeroporto do Rio de Janeiro em $1^{\circ}$ de fevereiro de 1933. O anteprojeto foi elaborado, optando-se pela forma elíptica, tendo o eixo maior orientado segundo o vento mais frequente. Como se pode ver na figura 5, o anteprojeto foi publicado na capa do jornal Correio da Manhã, de 27 de janeiro de 1933. Posteriormente, as sondagens hidrográficas e o aproveitamento do cais Leste-Oeste, já existente, e outros estudos aconselharam a forma retangular, como pode ser visto na figura 6 , que foi adotada no projeto final (HEMEROTECA DIGITAL DA BIBLIOTECA NACIONAL, 29/10/1936, p. 12). ${ }^{13}$

\footnotetext{
${ }^{12}$ HEMEROTECA DIGITAL DA BIBLIOTECA NACIONAL. Periódicos. O Cruzeiro, Rio de Janeiro, 6 set. 1941. p. 62.

${ }^{13}$ HEMEROTECA DigitAl DA BIBLIOTECA NACIONAL. Periódicos. Correio da Manhã, Rio de Janeiro, 29 out. 1936. p. 12.
} 


\section{Figura 5 - Anteprojeto do Aeroporto}

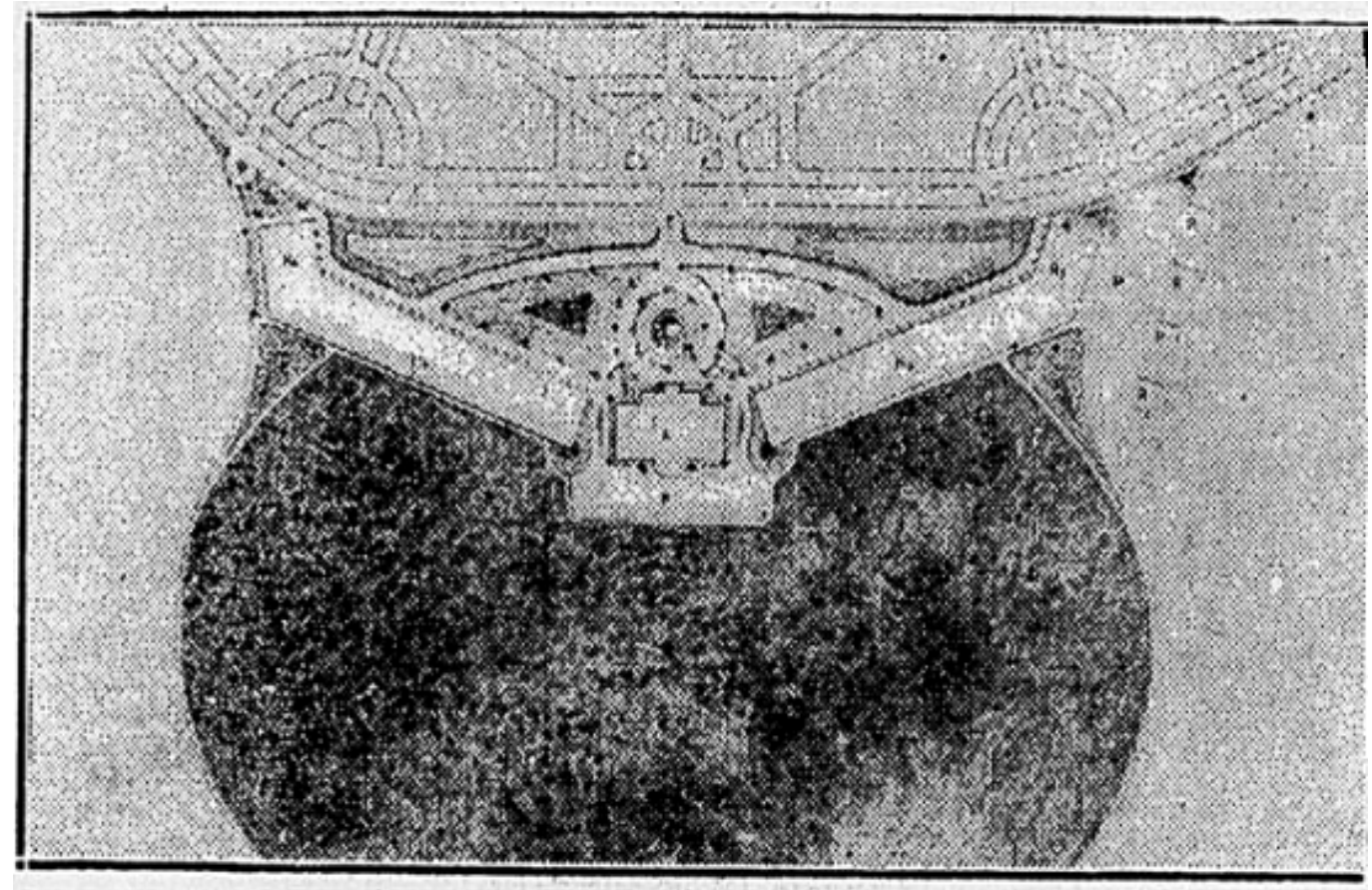

Fonte: (HEMEROTECA DIGITAL DA BIBLIOTECA NACIONAL, 27/01/1933, capa). ${ }^{14}$

\section{Figura 6 - Projeto do aeroporto}

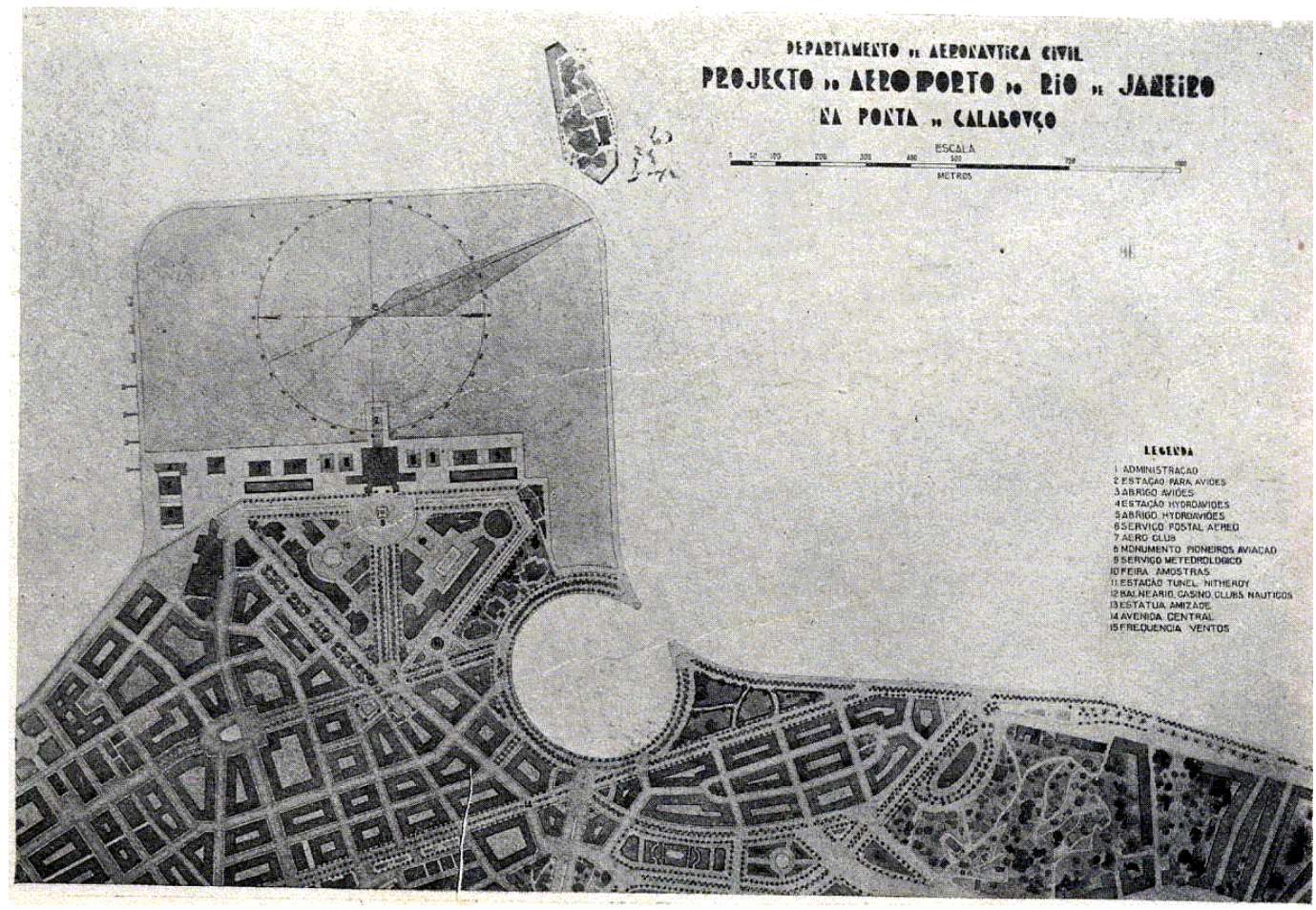

Fonte: (HEMEROTECA DIGITAL DA BIBLIOTECA NACIONAL, 20/10/1934, p. 38). ${ }^{15}$

${ }^{14}$ HEMEROTECA DIGITAL DA BIBLIOTECA NACIONAL. Periódicos. Correio da Manhã, Rio de Janeiro, 27 jan. 1933. Capa.

${ }^{15}$ HEMEROTECA DIGITAL DA BIBLIOTECA NACIONAL. Periódicos. O Cruzeiro, Rio de Janeiro, 20 out. 1934. p. 38. 
Figura 7 - Vista aérea do Rio de Janeiro

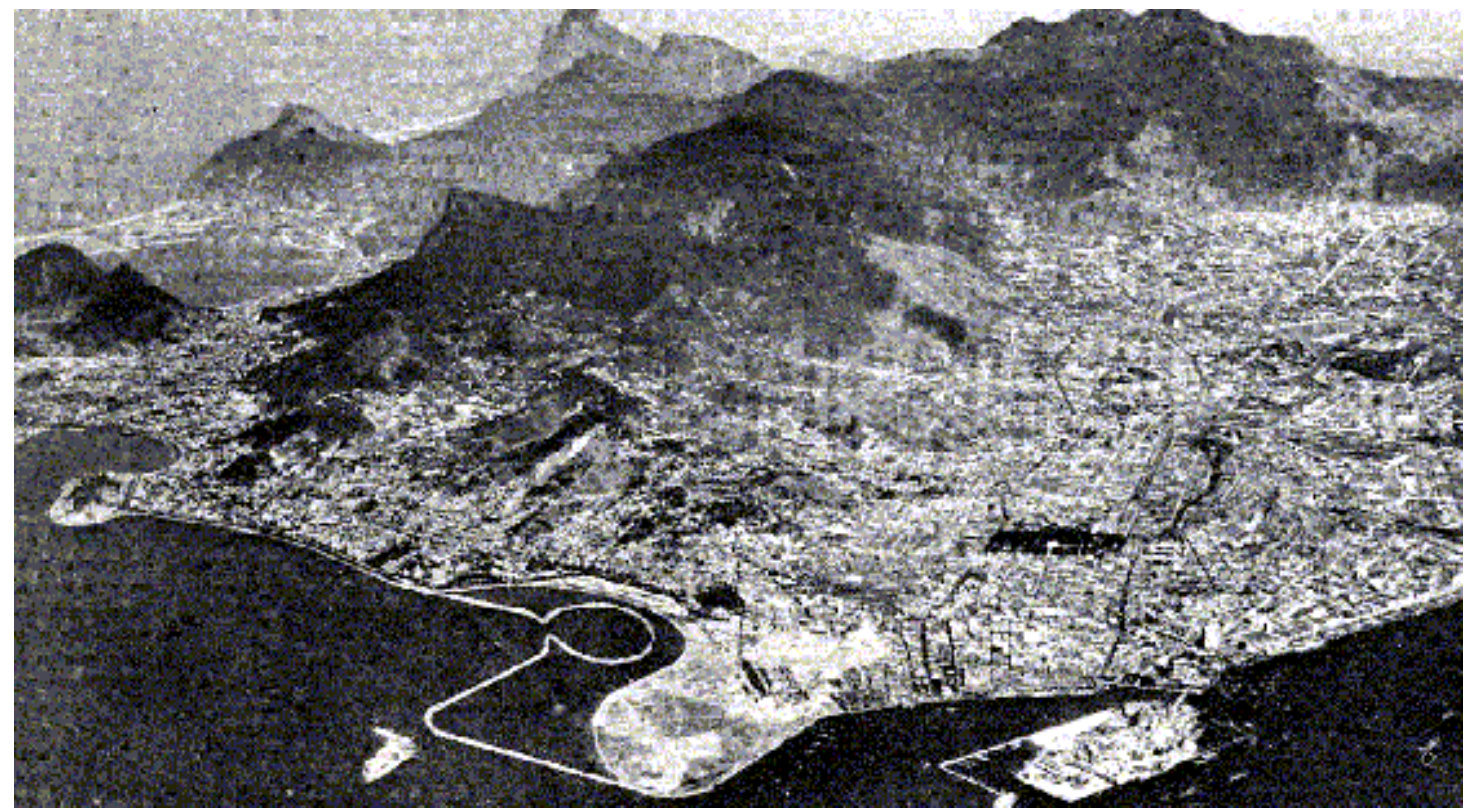

Fonte: (HEMEROTECA DIGITAL DA BIBLIOTECA NACIONAL, 20/10/1934, p. 38). ${ }^{16}$

A revista O Cruzeiro publicou em 1934 a imagem do local onde seria construído o novo aeroporto. Como pode ser observado na figura 7, a fotografia aérea mostra a beleza da cidade construída de frente para a baía da Guanabara; e uma linha branca indica o local que seria aterrado e onde deveriam ser construídas as pistas de pouso e o edifício para receber os passageiros. Pode-se ver que o aterro projetado forma um retângulo.

As obras, segundo o engenheiro César Grillo, deveriam preparar o terreno e construir um muro de contenção e depois as pistas e o conjunto de edifícios com serviços administrativos, aeronáuticos, alfândega, saúde, polícia, restaurante e bar, além de hangares para hidroaviões e para aviões. Esse conjunto seria uma entrada digna para o Rio de Janeiro oferecer aos turistas passageiros uma impressão condizente com suas belezas.

\footnotetext{
${ }^{16}$ HEMEROTECA Digital DA BIBlioteCA nACIONAL. Periódicos. O Cruzeiro, Rio de Janeiro, 20 out. 1934. p. 38.
} 


\section{Figura 8 - A Estação de hidroaviões na Ponta do Calabouço}

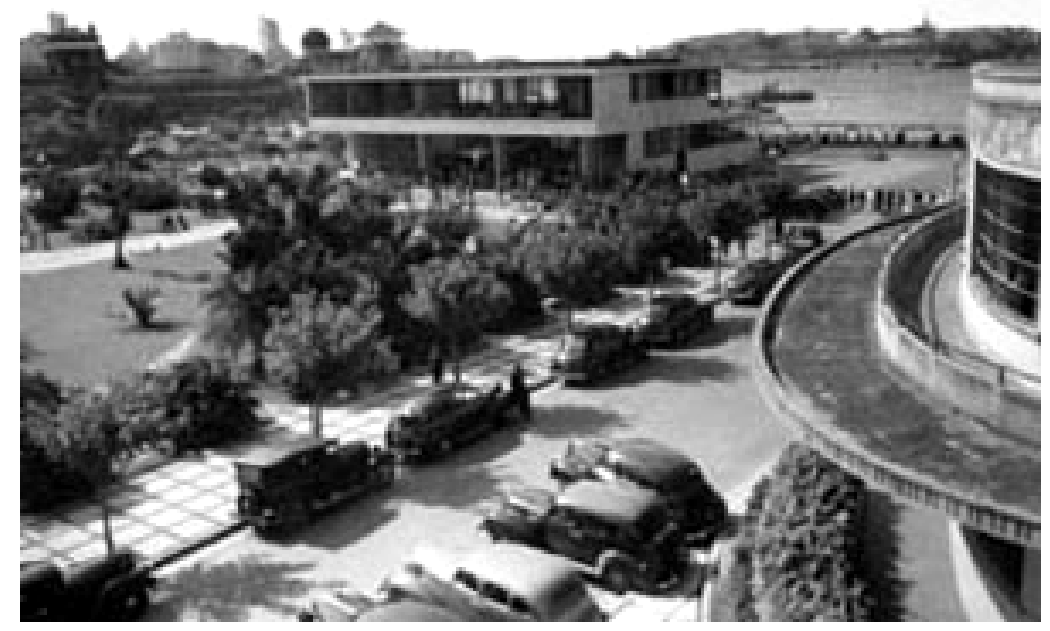

Fonte: Migliani (2014).

\section{A Estação de Hidroaviões}

No mesmo local onde seria construído o novo aeroporto estava sendo finalizada a construção da estação para hidroaviões, como pode ser visto na figura 8. Projetada pelo arquiteto Attilio Corrêa Lima, era inteiramente revestida de mármore, tanto interna como externamente $^{17}$, para o embarque e recepção de passageiros. A estação possuía um belíssimo jardim tropical para recepção dos passageiros das linhas transoceânicas, dando ao visitante a vista das belezas naturais.

Até esse momento, a necessidade de infraestrutura para aviação no Brasil era aquática, destinada ao pouso dos hidroaviões. Em meados da década de 1930 surgiram os primeiros aviões de fuselagem totalmente metálica como o JU52, de fabricação alemã, e o norte americano Douglas DC-3, lançados comercialmente nos anos 1935 e 1936. Esses aviões mais pesados - em torno de 10 toneladas - podiam transportar em torno de 20 passageiros e atingiam velocidades em torno de $300 \mathrm{~km}$ por hora, porém exigiam pistas de pouso maiores, superiores a 600 metros, e de preferência pavimentadas, embora pousassem em pista de terra ou grama. O Brasil possuía, na época, 117 campos de pouso com pistas precárias, mas uma capital federal necessitava de um aeroporto.

O Departamento de Aviação Civil enviou para a Europa e Estados Unidos um técnico a fim de estudar as melhores construções e adaptá-las para as conveniências

\footnotetext{
${ }^{17}$ Este Edifício ainda existe e hoje é a sede do Instituto Cultural da Aeronáutica (INCAER).
} 
nacionais. O Major Fontenelle, que era auxiliar técnico, foi convidado pela Pan American a conhecer as instalações e campos de pouso da empresa (HEMEROTECA DIGITAL DA BIBLIOTECA NACIONAL, 15/12/1934, p. 5). ${ }^{18}$

O projeto do novo aeroporto previa a utilização de uma área de $800.000 \mathrm{~m}^{2} \mathrm{e}$ contava com uma estação central para passageiros, torre de comando, serviços para voo cego, rádio e sinalização noturna, e quatro hangares de concreto armado. Em 1934, o jornal O Correio da Manhã $(6 / 07 / 1934)^{19}$ publicou a assinatura do contrato de construção do aeroporto com a Companhia de Construções Civis Hidráulicas pelo prazo de dezoito meses.

Enquanto se processava a construção, a aviação comercial se intensificava; em 1934 foram os norte-americanos que estabeleceram uma ligação regular (HEMEROTECA DIGITAL DA BIBLIOTECA NACIONAL, 19/08/1934, p. 11). ${ }^{20} \mathrm{~A}$ Pan American, orgulhosa, anunciava a chegada do Brazilian Clipper, um hidroavião comercial que estabelecia um elo de comunicações aéreas entre a América do Norte e a América do Sul.

Em 1935 as obras progrediam e a muralha de contorno estava quase terminada, assim como a pista de 300x500 metros (HEMEROTECA DIGITAL DA BIBLIOTECA NACIONAL, 17/01/1935, p. 7) ${ }^{21}$. Em setembro começou a ser utilizada para as operações uma pista de 400 metros, que um ano depois foi ampliada para 700 metros, e podia receber o tráfego de aviões comerciais de 109 toneladas. A mesma pista foi aumentada para mil metros e suportava o serviço regular da linha Rio-São Paulo realizada pela VASP; a linha da Panair do Brasil para Belo Horizonte era feita pelos aviões Lockheed Electra; a linha de Assunção e de Buenos Aires era da Pan American com aviões DC-3; e a Condor fazia a ligação com Buenos Aires também com o JU52.

As obras de preparo do campo seguiam um plano cuidadoso e várias dificuldades foram surgindo no curso dos trabalhos. Foi feita uma faixa com quase 200 metros de largura em todo comprimento, que se achava praticamente acabada, com drenagem, irrigação e gramado.

\footnotetext{
${ }^{18}$ HEMEROTECA Digital DA BIBLIOTECA NACIONAL. Periódicos. Correio da Manhã, Rio de Janeiro, 15 dez. 1934. p. 5.

${ }^{19}$ HEMEROTECA DIGITAL DA BIBLIOTECA NACIONAL. Periódicos. Correio da Manhã, Rio de Janeiro, 6 jul. 1934.

${ }^{20}$ HeMEROTECA Digital DA BIBLIOTECA NACIONAL. Periódicos. Correio da Manhã, Rio de Janeiro, 19 ago. 1934. p. 11.

${ }^{21}$ HeMEROTECA DigitAl DA BIBLIOTECA NACIONAL. Periódicos. Correio da Manhã, Rio de Janeiro, 17 jan. 1935. p. 7.
} 
A Vasp encomendou aviões para iniciar uma ligação entre São Paulo e Rio de Janeiro, e aguardava as obras do aeroporto de Congonhas quando os aviões chegaram em julho de 1936. Eram dois aviões Junkers JU52/3m da Alemanha, que foram batizados com os nomes Cidade de São Paulo (PP-SPD) e Cidade do Rio de Janeiro (PP-SPE), e entraram em serviço no dia 5 de agosto de 1936. Ainda com os dois aeroportos em obras, com o objetivo de inaugurar a rota, um dos aparelhos decolou de São Paulo com destino ao Rio de Janeiro e o outro do Rio com destino a São Paulo e ambos, ao pousar nos respectivos destinos, se acidentaram, causando pequenos danos. (PEREIRA, 1986, p. 185). No mês de novembro reiniciaram os serviços, depois de reparados.

A revista 0 Cruzeiro fez, em abril de 1938, uma fotorreportagem que destacava o fato de que o Governo Getúlio Vargas realizava "sem reclame as obras do aeroporto Santos Dumont”. A reportagem dava a entender que poucos sabiam o que estava ocorrendo na Ponta do Calabouço e, com fotos da obra e maquetes dos futuros edifícios, chamavam a atenção dos leitores para a visita de Trajano Furtado Reis, Diretor do Departamento de Aviação Civil, e do Diretor de Diários Associados, Assis Chateaubriand. A inauguração estava prevista para o mês de junho e nessa fase de censura política, do Estado Novo, elogiava o "Brasil Novo", que se modernizava (HEMEROTECA DIGITAL DA BIBLIOTECA NACIONAL, 21/04/1938, p. 16-17). ${ }^{22}$

$\mathrm{O}$ sentimento de modernidade $\mathrm{e}$ as conquistas da aviação continuavam empolgando os leitores das revistas, como se pode ver pelas mudanças que ocorriam na cidade. O Rio se transformava e seu aeroporto fazia parte dessa mudança, como demonstra uma crônica que a revista Ilustração Brasileira publicou em 1941, junto a uma reportagem que mostrava as alterações com fotos do Rio da época, revelando no do texto as mudanças da cidade. No texto que acompanhava as fotos, o cronista imaginou um carioca morto que voltasse ao Rio de Janeiro.

\begin{abstract}
Um carioca, morto há 30 anos que ressuscitasse hoje e fosse posto a andar da chamada Esplanada do Castelo, isto é, desde os fundos da Biblioteca Nacional, da Escola de Belas Artes, do Palace Hotel até a beira mar ao lado do obelisco e até o aeroporto Santos Dumont, julgar-se-ia numa cidade estranha e inteiramente desconhecida. Nada mais há por ali de outrora, nem as casas, nem o próprio terreno, pois a topografia local foi alterada por uma avalanche de construções modernas. (HEMEROTECA DIGITAL DA BIBLIOTECA NACIONAL, 1941, p. 23). ${ }^{23}$
\end{abstract}

\footnotetext{
${ }^{22}$ HEMEROTECA DIGITAL DA BIBLIOTECA NACIONAL. Periódicos. O Cruzeiro, Rio de Janeiro, 21 abr. 1938. p. 16-17.

${ }^{23}$ HEMEROTECA DIGITAL DA BIBLIOTECA NACIONAL. Ilustração Brasileira, Rio de Janeiro, v. 19, n. 77, set. 1941. p. 23.
} 
Motta (2004, p. 38) explica que, durante o período do Estado Novo, Vargas tinha um projeto claro para tornar a capital o lugar onde exerceria seu poder pessoal. Foram três empreendimentos principais: a abertura da Avenida Presidente Vargas, a construção dos prédios dos Ministérios da Educação e Saúde, do Trabalho e da Fazenda; e as comemorações cívicas realizadas no estádio do Clube Vasco da Gama. Houve, contudo, a substituição de marcos arquitetônicos, espaços tradicionais da cultura popular, que foram destruídos para construir a larga avenida.

Alguns anos depois, em 1949, outro cronista demonstrava sua preocupação afirmando que "a sopa iria acabar":

\begin{abstract}
O aeroporto Santos Dumont fica ali, no Calabouço, a dois passos da Câmara de Deputados e a cinco minutos do centro da cidade. Qualquer um pode ir levar ou buscar um parente ou amigo a pé. Pois esta sopa vai acabar... No futuro o desembarque vai ser no Galeão na ilha do governador e terá de gramar mais de uma hora de táxi... (HEMEROTECA DIGITAL DA BIBLIOTECA NACIONAL, 1950, p. 21). ${ }^{24}$
\end{abstract}

A preocupação e o sentimento de perda eram compreensíveis, pois na década de 1940 o aeroporto possuía voos que ligavam a cidade com todos os pontos do país com conforto e rapidez. A aviação continuava seu progresso técnico, com aviões maiores e mais pesados que não podiam pousar na pequena pista. Na década de 1950 aviões mais rápidos - a aviação a jato - começaram a operar e necessitavam de pistas mais longas, ocorrendo a separação entre os voos domésticos e internacionais, que foram transferidos para o aeroporto internacional do Galeão, hoje aeroporto Tom Jobim.

\title{
Considerações finais
}

O Rio de Janeiro conservou em funcionamento o aeroporto junto ao centro da cidade. Para o conforto dos usuários dos voos domésticos, o aeroporto Santos Dumont continua sendo utilizado; em 2015 passaram por lá nove milhões de passageiros ${ }^{25}$ e atualmente quatro empresas aéreas operam diariamente suas pistas (LATAM, Gol, Azul e Avianca Brasil). Mesmo aos mais apressados que embarcam, desembarcam, fazem conexões ou pegam a ponte aérea Rio-São Paulo, a sua paisagem ainda emociona com a vista da baía de Guanabara; poucos, no entanto, imaginam, ao pisar naquele solo que

\footnotetext{
${ }^{24}$ HeMeroteca digital DA BIBLIOTECA NACIONAL. Periódicos. Mais em terra que no ar. O Malho, Rio de Janeiro, ano XLVIII, n. 120, jan. 1950. p. 21.

${ }^{25}$ Informações Infraero 2016.
} 
antes era mar, que estão num aterro que foi feito a partir do desmonte de dois morros tradicionais da cidade. Seu edifício, com o arejado saguão repleto de colunas, também traz uma história da arquitetura moderna, projetada pelos irmãos Marcelo e Milton Roberto: uma imponente porta de entrada que promoveu o desenvolvimento da cidade. 


\section{REFERÊNCIAS}

\section{Fontes primárias}

AGACHE, Alfred (Coord.). Cidade do Rio de Janeiro: Extensão-RemodelaçãoEmbellezamento. Paris: Foyer Brésilien, 1930. Disponível em: <http://planourbano.rio. rj.gov.br>. Acesso em: 20 set. 2016.

HEMEROTECA DIGITAL DA BIBLIOTECA NACIONAL. Ilustração Brasileira, Rio de Janeiro, v. 19, n. 77, set. 1941. p. 23.

HEMEROTECA DIGITAL DA BIBLIOTECA NACIONAL. Periódicos. Correio da Manhã, Rio de Janeiro, 27 jan. 1933. Capa.

HEMEROTECA DIGITAL DA BIBLIOTECA NACIONAL. Periódicos. Correio da Manhã, Rio de Janeiro, 6 jul. 1934.

HEMEROTECA DIGITAL DA BIBLIOTECA NACIONAL. Periódicos. Correio da Manhã, Rio de Janeiro, 19 ago. 1934. p. 11.

HEMEROTECA DIGITAL DA BIBLIOTECA NACIONAL. Periódicos. Correio da Manhã, Rio de Janeiro, 15 dez. 1934. p. 5.

HEMEROTECA DIGITAL DA BIBLIOTECA NACIONAL. Periódicos. Correio da Manhã, Rio de Janeiro, 17 jan. 1935. p. 7.

HEMERotecA Digital DA BIBliotecA NACIONAL. Periódicos. Correio da Manhã, Rio de Janeiro, 29 out. 1936. p. 12.

HEMEROTECA Digital DA BIBlioteCA NACIONAL. Periódicos. Mais em terra que no ar. O Malho, Rio de Janeiro, ano XLVIII, n. 120, jan. 1950. p. 21.

HEMEROTECA DiGiTAL DA BIBLIOTECA NACIONAL. Periódicos. O Cruzeiro, Rio de Janeiro, 29 dez. 1928. p. 13.

HEMEROTECA DiGiTAL DA BIBLIOTECA NACIONAL. Periódicos. O Cruzeiro, Rio de Janeiro, 31 maio 1930. p. 1.

HEMEROTECA Digital DA BIBLIOTECA NACIONAL. Periódicos. O Cruzeiro, Rio de Janeiro, 13 out. 1932. p. 6.

HEMEROTECA Digital DA BIBLIOTECA NACIONAL. Periódicos. O Cruzeiro, Rio de Janeiro, 14 out. 1932. p. 5.

HEMEROTECA Digital DA BIBliotecA NACIONAL. Periódicos. O Cruzeiro, Rio de Janeiro, 13 out. 1934. p. 67.

HEMEROTECA DiGiTAL DA BIBLIOTECA NACIONAL. Periódicos. O Cruzeiro, Rio de Janeiro, 20 out. 1934. p. 6. 
HEMEROTECA DiGiTAL DA BIBLIOTECA NACIONAL. Periódicos. O Cruzeiro, Rio de Janeiro, 20 out. 1934. p. 8.

HEMEROTECA DIGITAL DA BIBLIOTECA NACIONAL. Periódicos. O Cruzeiro, Rio de Janeiro, 20 out. 1934. p. 23.

HEMERotecA Digital DA BIBLIOTECA NACIONAL. Periódicos. O Cruzeiro, Rio de Janeiro, 20 out. 1934. p. 38.

HEMEROTECA DigitAl DA BIBLIOTECA NACIONAL. Periódicos. O Cruzeiro, Rio de Janeiro, 21 abr. 1938. p. 16-17.

HEMEROTECA DIGITAL DA BIBLIOTECA NACIONAL. Periódicos. O Cruzeiro, Rio de Janeiro, 6 set. 1941. p. 62.

SILVA, Lucia. VASP Aviação Commercial. São Paulo: Revista dos Tribunaes, 1934.

\section{Fontes secundárias}

BARBOSA, Wilson. Aeroporto Santos Dumont: um grande portal do Rio. Rio de Janeiro: Revista Aeronáutica, 1985.

CHADEAU, Emmanuel. Le rêve et la puissance l'avion et son siecle. Paris: Fayard, 1996.

CHARTIER, Roger. Poderes e limites da representação: Marin, o discurso e a imagem. In: CHARTIER, Roger. À beira da falésia: a história entre certezas e inquietudes. Porto Alegre: UFRGS, 2002, p. 163-180.

DICIONÁRIO HISTÓRICO BIOGRÁFICO BRASILEIRO PÓS-1930. 2. ed. rev. e atual. Rio de Janeiro: FGV, 2001. v. I e II.

ELEUTÉRIO, Maria de Lourdes. Imprensa a serviço do progresso. In: MARTINS, Ana Luiza; LUCA, Tania Regina. História da Imprensa no Brasil. São Paulo: Contexto, 2008. p. 82-101.

GINZBURG, Carlo. Mitos, emblemas, sinais: morfologia e história. Tradução de Federico Carotti. 2. ed., 2. reimpr. São Paulo: Cia. das Letras, 1989.

LYNCH, Kevin. A imagem da cidade. 3. ed. São Paulo: Martins Fontes, 2011.

MAUAD, Ana Maria. Na Mira do Olhar: um exercício de análise da fotografia nas revistas ilustradas cariocas na primeira metade do século XX. Anais do Museu Paulista, São Paulo, v. 13, n. 1, p. 173-174, jan./jun. 2005.

MIGLIANI, Audrey. Clássicos da Arquitetura: Estação de Hidroaviões/Attilio Corrêa Lima. Publicado em: 27 ago. 2014. Disponível em: <http://www.archdaily.com.br/ br/626074/classicos-da-arquitetura-estacao-de-hidroavioes-attilio-correa-lima>. Acesso em: 20 set. 2016. 
MOTTA, Marly. Rio, cidade-capital. Rio de Janeiro: Zahar, 2004.

PEREIRA, Aldo. A breve história da aviação brasileira. Rio de Janeiro: Europa, 1986.

PESAVENTO, Sandra. Muito além do espaço: por uma história cultural do urbano. Estudos Históricos, Rio de Janeiro, v. 8, n. 16, p. 279-290, 1995.

ROSEAU, Nathalie. Aerocity: Quand l'avion fait la ville. Marseille: Éditions Parenthèses, 2012.

ROSEAU, Nathalie. Dal megaevento alla megastruttura L'aeroporto emblem della città globale. Le Culture Della Técnica, Torino, v. 25, p. 183-200, 2014.

SAINT-EXUPÉRY, Antoine de. Terra dos Homens. Rio de Janeiro: Nova Fronteira, 1986.

SEVCENKO, Nicolau. A capital irradiante: técnica, ritmos e ritos do Rio. In: NOVAIS, Fernando. História da Vida Privada. vol. 3. São Paulo: Companhia das Letras, 1998. p. 513-619.

WOHL, Robert. The spetacle of flight: aviation imagination, 1920-1950. New Haven and London: Yale University Press, 2005. 